\title{
一般 40
}

\section{フェブキソスタット内服に伴う, 尿酸排泄の変化}

背 景

高尿酸血症・痛風の治療ガイドラインでは, 高 尿酸血症の治療の際に，尿酸排泄低下型か尿酸産 生過剩型かの病型分類を行い, 病型に合った尿酸 降下薬を使用することが推奨されている.しかし, 副作用の少ない新薬の登場により, 腎機能が悪く てもキサンチンオキシダーゼ阻害薬が使用可能と なった。キサンチンオキシダーゼ阻害薬は, 尿酸 産生を低下させることで尿酸值 (UA) の低下が期 待される薬であるが，尿酸排泄に及ぼす影響につ いては不明な点が多い.

\section{目的}

キサンチンオキシダーゼ阻害薬であるフェブキ ソスタットを用いた加療により，尿酸排泄がどの ように変化するのか, 病型分類が变化するのかを 検討する。

\section{方 法}

20 歳以上で, 血清尿酸值 $8.0 \mathrm{mg} / \mathrm{dl}$ 以上かつ, 内服薬変更を 3 か月前から行っていない患者を対 象とし，フェブキソスタット内服開始前と，内服 12 週間後で，尿酸排泄に違いが生じるかを検討 した.フェブキソスタットは $10 \mathrm{mg}$ で内服開始し, 2 週間後に $20 \mathrm{mg}$ に増量, 以後 $20 \mathrm{mg}$ で内服継続と

\author{
桑原 政成 1,2) 丹羽公一郎2) 浜田 紀宏3) \\ 荻野 和秀4) 太田原 顕 ${ }^{5)}$ 水田栄之助 5 \\ 宮崎 聡6) 久留一郎7
}

した。尿酸排泄は, 尿 $\mathrm{UA} /$ 尿 $\mathrm{Cre}$, 尿中尿酸排泄率： FEUA（（尿UA/尿Cre）/(血清UA/血清 Cre）) で 検討を行った。

\section{結果}

16 人の男性 $(54.4 \pm 15.1$ 歳) を研究対象とした ベースの尿 UA/ 尿 Creが 0.52 を超える尿酸産生過 剒型の高尿酸血症は 2 人いたが, どちらもフェブ キソスタット内服後は 0.5 未満に低下していた. 尿 $\mathrm{UA} /$ 尿 Cre は 16 人中 15 人で，低下を認めてい た $(-0.17 \pm 0.11)$. 内服前の FEUA $<4 \%$ の尿酸排 泄低下型は 7 人いたが, フェブキソスタット内服 後には 3 人がFEUAの増加を認めていた。全体の FEUAは4.27士1.06\%から $3.71 \pm 1.40 \%$ に低下を認 めていた. 16 人中 12 人の FEUAが低下し, 新た に 5 人が FEUA $<4 \%$ の尿酸排泄低下型となった. FEUAは 4 人が増加していたが，そのうち 3 人は 尿酸排泄低下型の症例であった。

\section{結語}

フェブキソスタットの内服により，高尿酸血症 の病型分類が変わり，尿酸排泄低下型が増加する ことが示された。尿酸産生を抑えることが，尿酸 排泄量を低下させることにつながっていることが 明らかとなった。この事は高尿酸血症の一部に尿
1) 虎の門病院 循環器センター内科

2) 聖路加国際病院 循環器センター内科

3 ) 鳥取大学医学部 地域医療学講座

4 ）鳥取大学附属病院 検查部

5 ）山陰労災病院 循環器内科

6 ) 藤井将雄記念病院 内科

7 ) 鳥取大学大学院医学系研究科 機能再生医科学専攻 再生医療学部門
Masanari Kuwabara

Masanari Kuwabara, Kouichiro Niwa

Toshihiro Hamada

Kazuhide Ogino

Akira Ohtahara, Einosuke Mizuta

Satoshi Miyazuka

Ichiro Hisatome 
酸排泄低下型が関わっている可能性があることを 示し，フェブキソスタットに尿酸排泄促進薬の服 用が有効な場合があることを示唆する。もともと 尿酸排泄が低下している症例に対しては，一部の 症例で，フェブキソスタット内服により尿酸排泄 の増加を認めており，腎保護に働いている可能性 も示唆された。 